\title{
Arkiven på väg in i Cyberspace?
}

\section{Av Börje Björkman och Peter Danielsson}

\author{
Länk till presentation av Börje Björkman \\ Länk till presentation av Peter Danielsson
}

- IT som digital genväg

- Räkenskapsregister som ettor och nollor

- Hela kungariket?...nej men nästan halva!

- Öppet arkiv eller stängt?

- Tillgänglighet ja...men på vilket sätt?

- Arkiven - en omistlig del av vårt kulturarv

Vår svenska offentlighetsprincip - som ger varje svensk medborgare tillgång till allt offentligt arkivmaterial förutsatt att det inte omfattas av någon begränsning till följd av ålder eller hemlighet - har idag ett par hundra år på nacken. Ändå skulle man kunna hävda att de offentliga arkiven är på väg att öppnas än mer, att de nu blir tillgängliga för en större del av svenska folket än någonsin förut. Orsaken är den digitalisering som sker även inom arkivvärlden och som skulle kunna innebära ett lyft för forskarna, såväl för amatörerna som de mer professionella.

Digitaliseringen i sig är som bekant ingen specifikt svensk företeelse även om vi i Sverige har kommit långt om man räknar antalet datorer per innevånare och kanske är det så att det är amatörerna - inte minst de många släktforskarna - som kommit längre än proffsen vad gäller att ta datorerna och de växande databaserna i sin tjänst. Som exempel kan nämnas att det redan finns en del genealogiska databaser som är direkt sökbara via 'Nätet', främst amerikanska, men att försök pågår även i Sverige med att lägga ut olika kyrkliga längder on-line.[1]

\section{IT som digital genväg}

Säkerligen kommer detta arbete att fortsätta och utvecklas. Inom en icke alltför avlägsen framtid kommer man förmodligen att kunna göra mer kvalificerade sökningar än idag från hemdatorn och via Internet. Dock bör det tilläggas att det ännu så länge är ganska tungrodda söksystem vi talar om - i skrivande stund har man nog inte hittat sina bästa, i betydelsen mest användarvänliga, former. Ty även om tekniken har kommit långt så kräver databaser av denna typ, där man kan gå in i materialet och göra kvalificerade, kanske korsvisa, sökningar väldigt mycket både av lagringsutrymme och maskinkraft.

I de flesta fall handlar det därför fortfarande om att göra förteckningarna tillgängliga och att upprätta söksystem som kan underlätta det vardagliga forskarslitet. Sådana sökhjälpmedel finns dock flera exempel på redan idag. Den form man hittills oftast har valt är cd-rom-skivans. Ett par svenska exempel att nämnas kan vara den cd-rom-skiva innehållande de viktigaste emigrantarkiven som för några år sedan presenterades av Landsarkivet i Göteborg och som enligt ryktet nu är på väg att utvidgas och förbättras med fler register och fler sökingångar. Detsamma gäller den s.k. NAD-skivan - utläses Nationell Arkivdatabas - som offentliggjordes i en första version 1994. Som namnet antyder innehåller NAD förteckningar över de offentliga arkivens kataloger.[2] Riksarkivet, Krigsarkivet, landsarkiven men också ett antal lokala och regionala arkiv finns med liksom en del mindre arkiv, från enskilda personer, företag och föreningar vilka idag förvaras 
antingen i något av de nyssnämnda arkiven eller i något bibliotek eller museum. En gång har denna skiva uppdaterats men ytterligare förbättring lär vara 'på gång', i takt med att fler registreringar gjorts och fler arkiv inkluderats.

För den enskilde forskaren är NAD-skivan ett fantastiskt verktyg, inte minst genom att man med dess hjälp i förväg enkelt kan kontrollera vilken, exempelvis, statlig eller kommunal myndighet som har sitt arkiv på vilken plats och hur stort det är. På ett helt annat sätt än tidigare kan man alltså planera sina arkivresor och behöver inte längre åka på vinst och förlust i samma utsträckning som förr.

Inte heller NAD-skivan ger emellertid möjligheter att göra kvalificerade sökningar inuti själva arkiven, dvs så att man kan läsa enskilda handlingar och göra sökningar på nyckelord, namn eller liknande - dit har vi som antytts ännu en bit att vandra.

\section{Räkenskapsregister som ettor och nollor}

Ändå håller vi kanske på att ta de första stegen på denna väg - åtminstone att döma av de elektroniska sökregister som presenterades på en konferens om regionalt skattematerial på Riksarkivet i Stockholm 20-21 oktober 1998. Det handlade om att presentera resultaten av två olika digitaliseringsprojekt, benämnda SESAM I respektive II, vilka pågått under en treårsperiod som en del av en större satsning från Kulturdepartementet och som avslutas vid årsskiftet 1998/99. Flera olika digitaliseringsprojekt pågår vid Riksarkivet [3] men syftet med just de projekt som visades har varit att underlätta för vidare forskning i två alltmera sällan använda materialtyper - sällan använda kanske just för sin svårtillgänglighet. Vi talar om dels de s.k. Landskapshandlingarna från 1500- och 1600talen, dels länsstyrelsernas räkenskaper, ett kameralt material med startpunkt i 1630-talet. Tillsammans sträcker sig dessa databaser från 1530 till 1820. Visserligen är det även här fråga om sökregister, men de ger trots detta nya möjligheter att tränga in i ett mycket omfattande arkivmaterial på ett djupare, mer kvalitativt sätt.

Landskapshandlingarna har sitt ursprung i Gustav Vasas fogderäkenskaper. Som namnet antyder samlades handlingarna landskapsvis och förvarades i den kungliga 'kammaren', vilken senare blev till Kammararkivet som idag, i sin tur, ingår som en del i Riksarkivet. Här finns alla de jordeböcker och andra längder som möjliggjorde den genomgripande skattläggning som kungamakten genomdrev för hela landet, och de utgör därför ett mycket rikhaltigt material för den som idag vill veta något om den tidens ekonomi på såväl lokal som rikstäckande nivå. Förutom jordeböckerna finns här även exempelvis tiondelängder, enstaka domböcker och räkenskaper för de kungliga slotten respektive gårdarna.

Länsräkenskaperna kan i princip sägas ha avlöst landskapshandlingarna i takt med att de län som vi fortfarande till största delen har kvar tillkom under 1600-talet. Då delades även de olika fögderiernas handlingar upp på nytt, nu enligt länsgränserna, men inom dessa dock fortfarande samlade fögderivis. Från och med 1630-talet var det alltså till de nyupprättade länsstyrelserna, eller mer exakt till landskontoren, som fogdarna skickade in sina handlingar istället för som tidigare direkt till kungens kammare. Förutom jordeböckerna och andra redan nämnda typer av längder tillkommer i detta material en rad olika längder, som mantalslängder, räkenskaper för fängelser och fästningar, särskilda redovisningar för städerna, för diverse olika statliga och kyrkliga institutioner och byggnader, som hospital, kyrkorna i städerna, kronans spannmålsmagasin. Materialet i sig ger därför stora möjligheter att t.ex. studera förhållandena i fängelserna, brotten och fångarna, vart de transporterades och hur, deras medicinering vid sjukdom, liksom mer speciella förhållanden i krigstid, vad och hur mycket material som transporterades genom landet för trupper och eventuella krigsfångar, liksom transporter och kvantiteter av spannmål då hungersnöd utbrutit någonstans i landet. Årligen skulle nu fogdar och andra räkenskapsansvariga skicka in sina förvaltningsredovisningar dels till länsstyrelsen, dels till Stockholm. Landskontoren samlade alla dessa räkningar, verifikationer och vad det nu var, band samman, paginerade och sparade, i princip på samma sätt som skedde i Kammarkollegiet i Stockholm där revision också utfördes. 
I Sverige har vi av tradition varit väldigt bra på att spara våra arkiv. Inte minst gäller detta våra myndigheter på olika nivåer, och väldigt mycket finns kort sagt fortfarande bevarat, det vet var och en som har släktforskat eller som kanske försökt sig på att skriva en uppsats i exempelvis historia. Men en hel del arkivmaterial har också förstörts genom åren, inte minst genom bränder av vilka den ödesdigra branden på Stockholms slott år 1698 säkerligen var den största och mest skadebringande. Turligt nog - får man väl säga - hade statsmakten varit mycket noggrann då myndigheter och ämbetsverk byggdes upp och byråkratiserades alltmer - eftersom många olika typer av handlingar gjordes upp i flera exemplar och sedan arkiverades på olika ställen. Vad gäller de nyssnämnda materialtyperna finns länsstyrelsernas exemplar idag i respektive landsarkiv och kammarkollegiets i Riksarkivet - i den mån båda exemplaren faktiskt finns kvar bör väl kanske tilläggas.

Trots betydande luckor kan vi därför rekonstruera en hel del av det som försvunnit. Ett problem med dessa arkiv är dock att de varit svåra att överblicka och att utnyttja fullt ut: ofta band man ihop handlingarna kronologiskt eller tematiskt och register brydde man sig i en del fall inte ens om att upprätta. Det har till exempel varit svårt att få fram alla de uppgifter som finns i olika typer av längder rörande samma härad, socken eller gård, eftersom uppgifterna fördes på olika ställen och under olika rubriker.

Med de elektroniska sökregistren kan emellertid en hel del av dessa problem avhjälpas. Var för sig och tillsammans innehåller de ett stort antal olika sökmöjligheter. Man kan söka på olika typer av längder, tiondelängder, den årliga räntan, avkortningar av olika slag, men också finna enstaka domböcker, löningsregister, kvittenser och ett stort antal kungliga brev - som inte finns någon annanstans! Man kan här få fram uppgifter om antalet handlingar och omfattningen av desamma, eller söka på ett antal nyckelord - betydligt fler i länsräkenskapsbasen än i landskapsmotsvarigheten - som t.ex. alunbruk eller hammarbruk, gruva, gods, kloster, skola, hospital, verkstad, åtting etc etc.

Bara det faktum att man med registrens hjälp direkt kan få veta vilka handlingar som rör exempelvis ett visst magasin eller bruk beläget i ett visst härad, men som inte arkiverats i det egna länet utan i något grannlän, innebär stora förbättringar för forskaren. Man sparar mycket tid och man kan få en betydligt bättre helhetsbild.

Dock bör det tilläggas att man vid registreringen fått göra vissa begränsningar i typerna av sökposter: det går i princip inte att söka på de minsta kamerala enheterna, som enskilda socknar eller hemman. Skulle man ha gjort även denna registrering så hade man behövt engagera betydligt fler människor och använda ytterligare ett antal miljoner kronor, och man skulle inte ha varit färdig förrän om ett antal år. Att få med även de lägsta samhällsnivåerna har således inte varit varken tekniskt eller finansiellt möjligt.

\section{Hela kungariket?...nej men nästan halva!}

Onekligen var det trots begränsningarna imponerande resultat som kunde presenteras. Genom dessa upprättade datoriserade sökregister har väldigt mycket förenklats - vilket emellertid inte innebär att alla problem blivit lösta eller att hela landet har täckts. Ett problem med registret i sin nuvarande utformning är bland annat att flera län saknas.

Då projektet drogs igång för drygt tre år sedan och resurser erbjöds till de olika arkiven, avstod nämligen landsarkiven i Vadstena respektive Göteborg från att delta i arbetet med länsräkenskaperna. Kanske var detta nödvändigt då, men idag känns det mycket otillfredsställande att man inte var så framsynt att man insåg vilken potential detta sökregister kunde ha och prioriterade om de knappa personella och finansiella resurser man hade.

Som smålänning, öst- eller kanske västgöte kan man bara hoppas att man i efterhand på regional nivå - de centrala pengarna tycks man ha missat för alltid! - kan ragga upp ytterligare medel till en komplettering. 
Lite tråkigt är också att man inte redan från början inkluderade den tidigare finländska rikshalvan i projektet. Den byråkratiska delen av statsapparaten såg ju likadan ut i Finland som i det nuvarande Sverige och länsräkenskaperna där - uppgjorda enligt precis samma mall som för övriga län - förvaras idag, efter ett mellanspel hos de ryska myndigheterna, åter i de finländska arkiven. Det borde ha varit ganska enkelt att skapa ett samarbete över gränsen.

Även här får man hoppas att man på något sätt kan få till en komplettering av registret ty även detta skulle ge ett lyft åt framtidens forskningsmöjligheter. Som antytts är dock ingen av dessa kompletteringar planerad eller budgeterad på något sätt - de pengar som en gång gavs är slut och projekten avslutas vid kommande årsskifte. Förmodligen återstår det endast att man i såväl Finland som Sydsverige kan ragga upp tillräckliga medel för detta.

\section{Öppet arkiv eller stängt?}

Ett något paradoxalt resultat av registreringsarbetet har också blivit att samtidigt som man genom upprätta dessa sökregister öppnat fantastiska möjligheter för forskare av vitt skilda slag - söktrycket kommer säkerligen att ökas både på Riksarkivet och på de olika landsarkiven - så har konsekvensen blivit att stora delar av arkiven istället måste stängas!

Hur hänger detta ihop? Jo helt enkelt därför att man redan vid planeringen av projektet var så framsynt att man samtidigt med registrering och kategorisering av sökposter också gjorde en skadeinventering. Denna har i sin tur visat på ett enormt behov av mer eller mindre akuta åtgärder - åtgärder vilka man i dagsläget knappast kan vidtaga eftersom varken personal eller pengar finns att reparera och renovera. Ett par exempel: av de 1153 häften med handlingar (samlade i 435 volymer) som ingår i Dalarnas landskapshandlingar är hela 64\% i behov av vård, till följd av antingen fukt, brand eller mögel; i Östergötland än fler (69\%) och i Småland något färre (34\%). Fukten har för övrigt, totalt sett, gett upphov till de flesta skadorna, möglet till de minsta.

Det riktigt akuta renoveringsbehovet må vara begränsat - det rör sig om ungefär 5\% av det totala antalet häften - men är ändå så stort att man lugnt kan räkna med att arkiven inte kommer att ha råd att åtgärda ens detta, särskilt inte med tanke på de ytterligare sparkrav som hotar även arkiven.

\section{Tillgänglighet ja...men på vilket sätt?}

Ytterligare ett problem som också, åtminstone i viss mån, har med öppnandet och tillgången att göra och som återstår att lösa, består i att man ännu inte bestämt sig för vilken eller kanske vilka distributionsformer man skall välja för registren ifråga. Onekligen finns det flera skäl att fundera igenom detta mycket noggrant, bland annat därför att registren i sina nuvarande former såg lite olika ut - olika typer av databaser gjorda i olika typer av registerprogram - men också för att det är svårt att se in i framtiden och sia om vilken typ av teknik som kommer att vara den bästa. Inte minst på detta område går ju teknikutvecklingen redan mycket snabbt. De huvudsakliga alternativen som framfördes under diskussionen i Stockholm bestod - kanske inte helt oväntat - i att antingen producera en cd-rom-skiva eller någon form av 'on-line-tillgänglighet' via Internet.

Den sistnämnda varianten skulle förmodligen innebära att man öppnade för en begränsad 'on-line-sökning', exempelvis i form av att de olika landsarkiven skulle kunna koppla upp sig och direkt söka i databasen som fysiskt befinner sig på Riksarkivet i Stockholm. Att släppa registren helt 'fria' för sökning vore nog i dagsläget mycket svårgenomförbart, om inte annat så av rent tekniska skäl. Att för vart och ett av landsarkiven och för åtminstone de större biblioteken i landet 'köpa loss' en kopia skulle förmodligen bli ganska kostsamt. cd-rom-varianten skulle kunna genomföras antingen i form av en särskild produktion av en separat skiva just för de båda SESAM-registren, eller genom att man kopplar ihop dessa med den redan befintliga NAD-skivan. 
Vilket det blir återstår alltså att se, och det gäller definitivt att tänka sig noga för. Och hur det nu än blir med tillgängligheten så bör det också sägas att det redan idag faktiskt är möjligt att göra sökningar 'på distans'. I mån av tid ställer Riksarkivets personal redan nu upp på sådana beställningar.

\section{Arkiven - en omistlig del av vårt kulturarv}

Denna välorganiserade skattekonferens på Riksarkivet - som för övrigt avslutades med ett besök på Landsarkivet i Uppsala och utställningen Orostider i Uppland, vilken till stora delar byggts kring arkivmaterial av just denna typ - var något ganska unikt i den svenska arkivvärlden. Att arkiven på detta sätt inbjuder forskare och institutioner av det mest skilda slag till en gemensam presentation hör absolut inte till vanligheterna. Detta var enligt uppgift första gången som man åtminstone från Riksarkivets sida gjorde något sådant. Inte heller är det särskilt vanligt att de som arrangerar konferenser så generöst bjuder på allt, förutom deltagarnas resor och egna boende, inklusive den avslutande gemensamma utflykten.

Man kan bara hoppas att fler konferensarrangörer följer i Riksarkivets fotspår! Intresset för vad som händer på den svenska arkivfronten är nämligen stort, vilket visades tydligt av att drygt 35 personer hade slutit upp och gärna trängdes och trivdes i dagarna två. Bland oss fanns såväl amatörer som mer professionella forskare, såväl musei- som arkivfolk och därtill från både Sverige och Finland. Säkerligen bidrog den 'låga' deltagarkostnaden till att så många deltagare hade mött upp, men som sagt: intresset för vad som händer på både arkiv- och IT-fronten är stort och växande! De svenska forskare som idag inte använder datorn i något led är säkerligen ganska lätt räknade, kanske räcker det med ena handens fingrar.

Oavsett vilken lösning man väljer för att distribuera de elektroniska sökregistren över landskaps- och länsräkenskaperna så håller nu Internet och i synnerhet den s.k. World Wide Web (WWW) - äntligen! - på att bli det användbara redskap för forskning som det så länge sagts vara, dvs användbart även för mer seriösa och djuplodande forskningsuppgifter. På andra nivåer, exempelvis för undervisningen på grundskole- och gymnasienivå, har Internet redan blivit ett utmärkt komplement till de vanliga skolböckerna. Redan idag kan Internet utan tvekan fungera som ett inspirerande verktyg för den som har tillgång till program, maskiner och kablar. Även om 'Nätet' aldrig, förmodligen inte ens på sikt, helt kan ersätta de 'vanliga' arkiven och biblioteken öppnas fler och fler möjliga användningsområden.

Inte minst för de offentliga arkivens verksamhet och tillgänglighet skulle fler digitaliseringsprojekt av den typ som SESAM representerar kunna ge verkliga lyft, ur demokratisk synpunkt men också - och inte minst - ur bevarandesynpunkt. Arkiven är till för alla, men de handlingar som finns där utsätts för ett allt större slitage: ju fler forskare desto fler 'tummar' blir det, kort sagt. Genom ordentliga satsningar på digitalisering av arkivmaterial skulle vi kunna undvika att den internationellt sett unika källa till kunskap om det förflutna som de svenska myndighetsarkiven faktiskt utgör går förlorad.

\section{(C) Börje Björkman och Peter Danielsson}

[1] Ett stort antal World Wide Web-länkar skulle här kunna lämnas som ingångspunkter till denna värld som håller på att öppnas. Men varför inte börja på det svenska Riksarkivet http://www.ra.se/, ["Välkommen till Riksarkivet och landsarkiven"] - varifrån man sedan kan ta sig vidare ut i världen.

[2] För mer information se http://www.ra.se/NAD/NAD cd.htm ["NAD på cd-rom"].

[3] För en förteckning över de projekt som är igång just nu se http://www.ra.se/arkion/projekt/projekt.htm ["Projekt"]. 
Börje Björkman och Peter Danielsson, 'Arkiven på väg in i Cyberspace?'

Länkarna kontrollerade 1998-11-28.

http://www.vxu.se/hum/publ/humanetten/nummer3/art9809.html[2010-05-26 14:37:24] 